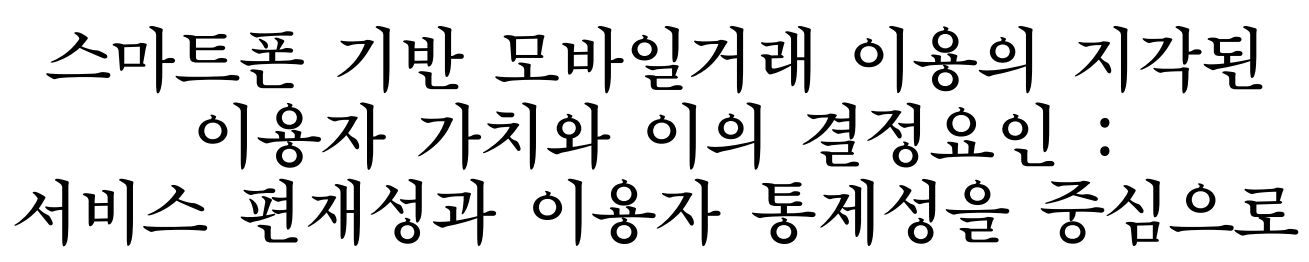

\title{
Determinants of User Perceived Value and Its Influence on the Usage of Smartphone- based Mobile Commerce : Focusing on Service Ubiquity and User Control
}

\author{
최수정(Sujeong Choi)*
}

\section{초 록}

본 연구는 스마트폰 기반 모바일거래를 통해 이용자가 추구하는 핵심 가치가 무엇인지 파악하고, 이러한 가치가 이용행위에 미치는 효과를 검증한다. 구체적으로, 본 연구는 이용자의 지각된 가치를 시간적 가치, 기능적 가치, 경제적 가치의 세 가지 차원으로 개념화하고 모바일거래 이용에 미치는 개별적인 효과를 검증한다. 이와 더불어, 본 연구는 스마트폰 기반 모바일거래의 핵심특성으로 서비스 편재성과 이용자 통제성을 제시하고, 어떻게 이들 특성들이 이용자의 핵심 가치 창출과 관련되어 있는지를 규명하고자 한다. 스마트폰 기반 모바일거래 이용자를 대상으로 수집한 164 개의 데이터를 가지고 PLS 분석을 한 결과는 다음과 같다. 첫째, 스마트폰 기반 모바일거래 이용은 시간적, 기능적, 경제적 가치들에 의해 결정되며 특히, 시간적 가치의 영향력이 가장 큰 것으로 나타났다. 둘째, 서비스 편재성은 시간적 가치에 유의척이지만 기능적 가치에는 비유의적인 것으로 나타났다. 마지막으로, 이용자 통제성은 시간적 가치 및 기능적 가치에 모두 영향을 미치는 것으로 나타났다. 종합적으로, 본 연구결과는 모바일거래의 이용이 시간적 가치에 의해 상당히 영향을 받으며, 시간적 가치는 서비스 편재성과 이용자 통제성에 의해 증가함을 제시한다.

\section{ABSTRACT}

This study attempts to identify user perceived value as a major predictor of the usage of smartphone-based mobile commerce $\left(\mathrm{m}^{-}\right.$-commerce). More specifically, the study concep ${ }^{-}$ tualizes user perceived value of smartphone-based $\mathrm{m}$-commerce along three dimensions, such as temporal, functional, and economic values. Moreover, this study proposes service ubiquity and user control that are uniquely defining characteristics of smartphone-based $\mathrm{m}-$-commerce and examines how the two variables are associated with the creation of user perceived value. Using a total of 164 data collected on users of smartphone-based $\mathrm{m}^{-}$ commerce, we conducted PLS analysis to test the proposed model and hypotheses. The key findings are as follows : First, it has been found that the usage of smartphone-based $\mathrm{m}-$ commerce is determined by the three values, such as temporal, functional, and economic values. Particularly, the results show that temporal value is the most influential variable in predicting $\mathrm{m}^{-}$-commerce use. Second, the results demonstrate that service ubiquity has a significant positive effect on temporal value, whereas it has no effect on functional value. Finally, user control is positively associated with temporal and functional values. Overall, the results indicate that service ubiquity and user control considerably increase temporal value, thereby accelerating the use of smartphone-based $\mathrm{m}^{-}$-commerce. Discussions and implications of the results are provided.

키워드 : 스마트폰, 모바일거래, 지각된 이용자 가치, 서비스 편재성, 이용자 통제성 Smartphone, Mobile Commerce, User Perceived Value, Service Ubiquity, User Control

* Corresponding Author, Free 21+ e-Service Team, Chonnam National University(mischoisj@jnu.ac.kr) 2013년 10월 05일 접수, 2013년 11월 01일 심사완료 후 2013년 11월 19일 게재확정. 


\section{1. 서 론}

모바일거래는 이용자에게 새로운 서비스 가 치를 제공한다[35]. 모바일거래는 전자적인 서 비스 거래를 지원하는 무선기기를 이용한 거 래를 가리킨다. 오늘날 대표적인 무선기기인 스마트폰은 고객에게 새로운 가치를 부가한 서비스 거래를 효과적으로 전달하는데 이용되 고 있다[46]. 일반적으로 모바일거래는 전자상 거래의 확장으로 개념화되기도 하지만 고객에 게 고유한 가치를 전달하는 독립된 채널로써 고려되는 것이 바람직하다[4]. 전통적인 오프 라인 기반 소매기업(예 : 은행)과 온라인 기업 (예 : 아마존)은 자사의 서비스 운영채널에 모 바일거래를 추가하고 있다[35]. 그럼에도 불구 하고, 기업은 모바일거래로부터 많은 이익을 창출하지는 못하고 있으며, 그 이유는 기업이 모바일거래를 통해 이용자가 얻고자 하는 실 용적 가치(Utilitarian Value)를 제대로 이해하 지 못하였기 때문이라는 지적이 존재한다[35, 52]. 그러므로 스마트폰 기반 모바일거래를 통 해 이용자가 추구하는 핵심 가치가 무엇인지 규명하고, 이러한 핵심 가치가 이용행위에 미 치는 효과를 이해할 필요가 있다. 이와 더불 어, 모바일거래 상황에서 이용자의 핵심 가치 를 결정하는 요인들은 무엇인지 동시에 규명 하는 것이 필요하다. 즉, 모바일거래와 관련된 고유한 특성들을 이해하고 이러한 특성들이 어떻게 이용자의 가치 창출과 관련되어 있는 지를 이해하는 것이 필요하다.

본 연구는 첫째, 소비가치에 관한 기존문헌 을 토대로 스마트폰 기반 모바일거래를 통해 이용자가 추구하는 핵심 가치들을 규명한다. 오랫동안 IS 연구자들은 IS 이용을 통해 원하
는 목표를 달성하거나 높은 성과를 추구하는 과업지향적인 이용 상황에서 실용적 가치 또 는 외재적 가치(Extrinsic Value)를 반영하는 지각된 유용성이 개인의 행위(의도)에 매우 영향 력 있는 변수임을 제시했다[19]. 대조적으로, 이용 그 자체에서 재미와 즐거움을 추구하는 쾌락적 IS 환경에서는 쾌락적 가치(Hedonic value) 또 는 내재적 가치(Intrinsic Value)를 반영하는 지각된 즐거움이 더욱 영향력 있는 변수임을 주 장했다[15, 41, 60]. 스마트폰 기반 모바일거래는 모바일 SNS(Social Networking Services), 모 바일 오락서비스 등과 같이 쾌락적 이용 상황 이 아니라 거래완료를 통해 특정성과를 달성 하려는 과업지향적인 이용 상황이라는 점에서 이용자가 추구하는 가치에 차이가 존재할 수 있다. 하지만, 모바일 서비스에 초점을 맞춘 대다수 선행연구들은 IS의 쾌락적 상황에서 이용자가 추구하는 핵심 가치들을 파악하고 이의 영향력을 규명하는데 초점을 맞추고 있 어[15, 34, 43, 57, 58], 모바일거래와 같이 실 용적인 혜택이 강조되는 목적 지향적인 이용 상황에서 이용자가 추구하는 핵심 가치에 관 한 연구는 상대적으로 부족하다[35]. 본 연구 는 스마트폰 기반 모바일거래가 이용자에게 어떠한 새로운 가치들을 창출하고 있는지를 규명함으로써 기업이 모바일거래 활성화를 위 해 어떠한 가치들에 더욱 중점을 두어야 하는 지를 제안하고자 한다.

구체적으로 본 연구는 스마트폰 기반 모바일거 래에서 이용자가 추구하는 지각된 가치를 시간적 가치(Temporal Value), 기능적 가치(Functional Value), 경제적 가치(Economic Value)의 세 가지 차원으로 개념화하고 모바일거래 이용에 미치 는 효과를 검증한다. 기능적 가치는 스마트폰 
기반 모바일거래를 통해 이용자가 획득 가능 한 성과측면의 효용(Utility)에 관한 평가를 의미하며[34, 54], 경제적 가치는 스마트폰 기 반 모바일거래가 이용자에게 제공하는 금전적 인 측면의 효용에 관한 평가를 의미한다[34, 44, 57]. 이 두 차원은 제품 또는 서비스의 이 용으로부터 이용자가 추구하는 대표적인 실용 적 측면의 가치들이다. 이와 더불어, 본 연구 는 시간적 가치를 스마트폰 기반 모바일거래 가 이용자에게 제공하는 시간 편의성과 관련 된 효용으로 정의하고[35, 56], 모바일거래에 서 이용자의 핵심 가치 차원 중의 하나로써 추가한다. 이용자가 종업원과의 직접적인 상 호작용 없이 스스로 서비스를 창출하는 모바 일거래를 선택하는 핵심 이유 중의 하나는 시 간절약 때문이다 $[35,46]$. 스마트폰 기반 모바 일거래는 빠른 거래를 통한 시간의 절약과 효 율적인 사용 측면에서 상당한 혜택을 창출할 있을 것이다. 본 연구는 이러한 세 가지 가치 차원들이 이용행위에 미치는 개별적인 효과를 규명하고자 한다.

둘째, 본 연구는 스마트폰 기반 모바일거래 상황에서 이용자의 가치를 결정하는 모바일특성 변수들을 규명하고자 한다. 즉, 모바일거래의 어 떠한 특성들이 이용자의 가치 창출에 영향을 미치는지를 이해하고자 한다. 구체적으로, 본 연구는 서비스 편재성(Service Ubiquity)과 이 용자 통제성(User Control)을 제시한다. 서비 스 편재성은 이용자가 스마트폰을 이용하여 언제 어디서든지 시간과 장소의 제약 없이 필 요한 정보와 서비스에 접근하여 원하는 모바 일거래를 수행할 수 있는 정도를 의미한다[40, 42, 56]. 서비스 편재성은 스마트폰과 같은 모 바일기기에 의해 더욱 강화된 모바일거래의
핵심 특성으로 모바일거래에 관한 이용자의 가치 평가에 상당한 영향을 미칠 수 있을 것 이다. 다음으로, 이용자 통제성은 이용자가 스 마트폰 기반 모바일거래에서 거래과정과 결과 에 관하여 스스로 선택하고 결정할 수 있는 정도를 의미한다[16, 35]. 고객이 종업원과의 직접적인 상호작용이 없는 셀프 서비스 거래 를 선택하는 또 다른 핵심이유는 스스로 원하 는 서비스를 선택하고 결정할 수 있다는 점이 다 $[5,37]$. 스마트폰 기반 모바일거래는 이용 자가 스스로 거래를 시작하고 완료하는 셀프 서비스 환경으로 이용자 통제성은 모바일거래 에 관한 가치 창출에 영향을 줄 수 있을 것이 다. 본 연구는 모바일거래의 핵심특성인 서비 스 편재성과 이용자 통제성이 앞서 제시한 세 가지 가치 차원들과 어떻게 관련되어 있는지 를 밝히고자 한다.

\section{2. 이론적 배경}

\section{1 이용자의 지각된 가치}

지각된 가치는 고객의 행위의도 및 실제행 위(예, 제품 또는 서비스 이용, 충성도)를 결 정하는 핵심 선행변수로서 강조되었으며, 다 양한 거래 및 서비스 상황에서, 서비스 품질 또는 이용 혜택이 행위의도에 미치는 효과를 일관되게 매개하는 것으로 제시되고 있다[10, 62]. 지각된 가치는 제품 또는 서비스가 제공 하는 효용에 관한 소비자의 종합적 평가를 의 미한다[62]. 이러한 평가는 제품 또는 서비스로 부터 획득한 혜택과 이를 위해 지출한 금전적 및 비금전적 비용의 비교를 통해 결정된다[62]. 
즉, 지각된 가치는 혜택과 비용의 상쇄관계(Tradeoff)에 관한 고객지각을 의미하며[10], 개인 및 상 황에 따라 상대적인 개념이다[27].

고객은 제품 또는 서비스의 이용을 통해 다 양한 가치를 추구한다[25]. 일반적으로, 오프라 인뿐만 아니라 온라인 소매 상황에서 이용자가 추구하는 지각된 가치는 실용적 가치 및 쾌락적 가치로 구분된다[25, 44]. 유사하게, Holbrook [27]은 제품소비를 통해 고객이 경험할 수 있 는 지각된 가치를 외재적 가치와 내재적 가치 의 두 가지로 개념화하였다. 즉, 고객은 제품 또는 서비스 이용의 결과로써 발생하는 혜택 들을 통해 기본적으로 실용적 가치 또는 외재적 가치를 추구한다[26]. 이와 더불어, 제품 또는 서비스 이용 그 자체가 고객에게 가치를 제공할 수 있으며, 이것이 쾌락적 가치 또는 내재적 가치이 다 $[2,3,26]$. 다시 말해서, 쾌락적 가치는 이용 그 자체에서 '재미(Fun)'와 '즐거움(Playfulness)' 을 경험하는 것을 가리킨다. 일반적으로, 외재 적 가치는 실용성을 추구하는 소매 상황에서 강조된다[26]. 대조적으로, 내재적 가치는 소 비결과로써 발생하는 성과와는 관계없이, 이 용경험 그 자체에 대한 평가에서 기인한다[27]. Babin 등[3]은 주관적 및 개인적인 특성이 강 하게 내포된 내재적 가치가 과업완수보다는 소비경험의 재미와 즐거움에 의해 발생한다고 주장했다.

소비가치에 관한 연구는 다양한 맥락에서 이용자가 추구하는 가치의 유형을 보다 구체 적으로 규명하고자 노력해 왔다. 제품의 소비 상황에서, Sweeney와 Soutar[54]은 Sheth 등 [53]의 가치유형을 토대로 제품소비를 통해 이용자가 추구하는 가치를 금전적 측면의 기 능적 가치(Price/Value for Money), 성과품질
측면의 기능적 가치(Performance/Quality), 정 서적(Emotional), 사회적(Social) 가치의 네 가 지 유형으로 개념화했다. 즉, 소비자 선택의 가 장 중요한 영향요인으로 강조된 기능적 가치 (Functional Value)는 제품의 속성 즉, 신뢰성, 내구성, 품질, 가격 등에 의해 도출된다[53]. 정 서적 가치는 제품이 생성하는 느낌(Feelings) 또는 감정적 상태에서 기인하는 효용이며, 사 회적 가치는 제품이 사회적 자아개념을 향상 시키는 것으로부터 도출되는 효용이다. 서비스 맥락에서, Petrick[47]는 서비스에 관한 지각 된 가치를 품질(서비스 우수성), 정서적 반응 (즐거움), 금전적 가격, 행위적 가격(비금전적 가격), 평판의 다섯 가지 차원으로 개념화했 다. 인터넷과 카탈로그 쇼핑의 두 가지 상황에 서, Mathwick 등[44]은 지각된 가치를 심미성 (Aesthetics), 유희성(Playfulness), 서비스 우 수성(Service Excellence), 고객 투자수익율의 네 가지 차원으로 개념화하고 각 차원의 세부 가치 요인들을 제시했다. 심미성과 유희성은 제품 또는 서비스의 이용 그 자체에서 즐거움 을 추구하는 쾌락적 가치를 반영하며, 서비스 우수성은 이용의 성과물에 대한 평가로써 실 용적 가치를 반영한다.

IS 연구자들은 지각된 가치의 개념을 도입 하여, IS 이용을 통해 개인이 추구하는 가치 가 무엇인지 규명하고자 노력해 왔다. $\mathrm{Kim}$ 등 [34]은 소셜 네트워킹 커뮤니티의 이용자들이 디지털 아이템의 구매를 통해 추구하는 가치 들을 기능적, 정서적, 사회적 가치의 세 가지 차원을 중심으로 제시하였다. 구체적으로, 기 능적 가치는 가격효용과 기능적 품질을, 정서 적 가치는 심미성, 즐거움을, 사회적 가치는 사회적 자아표현과 사회적 관계지원을 포함하 
는 것으로 제시했다. 이들의 연구결과는 심미성, 유희성, 사회적 자아표현이 디지털 아이템의 구매의도에 유의적인 영향을 주는 반면에 가 격효용, 기능적 품질, 사회적 관계지원은 구매 의도에 비유의적인 것으로 나타났다. Turel 등 [58]은 모바일 SMS(Short Messaging Services)의 이용자 수용을 결정하는 핵심 선행변 수로서 지각된 가치를 제시하고, 이용자의 지 각된 가치가 성과/품질 가치, 정서적 가치, 금 전적 가치, 사회적 가치의 네 가지 하위요인에 의해 형성된다고 주장했다. 이들의 연구결과는 사회적 가치를 제외한 나머지 세 가지 가치에 의해 형성된 지각된 가치가 SMS 이용의도를 상당히 증가시키고 궁극적으로 실제이용에도 영향을 주는 것으로 나타났다. 스마트폰에 기 반한 쾌락적 디지털 제작물(즉, 음악 다운로 드 서비스)의 이용자 수용에 관한 연구에서도, Turel 등[57]은 이용자의 종합적 가치가 행위 의도 및 긍정적 구전과 같은 행위를 결정한다 고 주장했으며, 종합적 가치는 시각적/음악적 소구가치, 사회적 가치, 금전적 가치, 유희성 가치의 네 가지 가치에 의해 형성되는 것으로 이론화했다. 이들의 연구결과는 사회적 가치가 종합적 가치에 미치는 효과는 비유의적인 것 으로 밝혀졌다. 소셜 네트워킹 사이트의 지불 의도에 관한 연구에서, $\mathrm{Lu}$ 와 Hsiao[43]는 이 용자의 지각된 가치가 만족과 지불의도에 직 접적인 영향을 미치며, 지각된 가치는 성과/품 질 가치, 정서적 가치, 사회적 가치, 금전적 가 치의 네 가지 가치에 의해 영향을 받는다고 가설화했다. 연구결과는 지각된 가치가 만족 과 지불의도를 상당히 증가시키지만 만족은 지불의도와 직접적인 관련이 없는 것으로 나 타났으며, 지각된 가치는 네 가지 가치에 의해
영향을 받는 것으로 나타났다. 최근에 출판된 Venkatesh 등[61]의 연구는 UTAUT (Unified Theory of Acceptance and Use of Techno$\operatorname{logy})$ 를 확장한 UTAUT2에서 쾌락적 동기 (즉, 지각된 즐거움), 가격가치, 습관의 변수를 새롭게 추가하여 이용자의 행위의도와 실제행위 에 미치는 효과를 규명했다. UTAUT가 작업 장 상황에서 개발된 모형인데 비해 UTAUT2 는 모바일 인터넷 소비자 상황에서 개발된 모 형으로 소비자의 효용관점에서 쾌락적 동기와 비용관점에서 가격가치를 새롭게 포함하여 기 존의 모형을 확장시켰다.

\section{2 모바일거래에서 시간적 가치}

모바일거래는 모바일 커뮤니케이션 또는 오 락 서비스의 이용 상황과는 대조적으로 이용자 의 실용적 가치가 크게 강조된다[46]. 즉, 모바 일거래는 이용성과가 강조되는 목표지향적인 상황이대[21]. Fiore 등[21]은 도구적(Instrumental) 또는 실용적 가치가 모바일거래를 완수하려는 소비자의 목표와 직접적으로 관련되어, 소비 자의 이용의도를 이끌어 낸다고 주장했다. 이 와 같이, 소비자는 모바일거래를 통해 자신의 특정 목표 또는 과업을 완수하고자 원하기 때 문에, 이용성과, 보상 등의 실용적 혜택에 의 해 동기 부여된다[46]. 그러므로 모바일거래에 서 이용자의 핵심 가치는 이용경험에서 재미 와 즐거움을 추구하는 내재적 가치보다는 성 공적인 결과물을 추구하는 실용적 가치에 의 해 결정된다[44]. 이와 같이, 모바일거래에서 이용자가 추구하는 핵심 가치는 쾌락적인 가 치를 추구하는 서비스와는 차이가 존재할 수 있다. 하지만, 앞장에서 제시한 것과 같이, 스 
마트폰을 포함한 모바일 기기를 대상으로 한 선행연구들은 IS 이용의 쾌락적 환경을 대 상으로 이용자의 핵심 가치를 파악하고 이의 효과를 규명하는데 중점을 두었다.

이와 더불어, 소비가치에 관한 선행연구는 다양한 맥락에서 다양한 유형의 가치를 제시 하였다. 일반적으로, 연구자들은 지각된 가치를 기능적 가치(성과품질 가치), 쾌락적 가치(정 서적 가치), 사회적 가치, 경제적 가치(금전적 가치)의 네 가지 차원을 포함하는 것으로 개념 화하였다[34, 43, 54, 58]. 이러한 가치 중에서, 기능적 및 경제적 가치는 이용성과를 강조하 는 외재적 가치에 해당되며, 쾌락적 가치는 이용과정의 경험을 강조하는 대표적인 내재적 가치에 해당된다[26, 44]. Turel 등[57]은 쾌락 적 상황에 적합한 내재적 가치로서 쾌락적 가 치와 사회적 가치를 포함하고 있다. 그러므로 본 연구는 스마트폰 기반 모바일거래가 이용 성과가 강조되는 목적지향적, 실용적 이용환 경이라는 점에서, 이용자의 핵심 가치로서 기 능적 가치와 경제적 가치를 포함하고, 모바일 $\mathrm{SNS}$ 또는 모바일 오락서비스 환경에서 강조 되는 쾌락적 가치와 사회적 가치는 제외하였다. 이에 추가적으로, 본 연구는 모바일거래 환경에 서 더욱 강화될 수 있는 이용자의 핵심 가치로 서 시간적 가치를 제시하고자 한다.

모바일거래에 초점을 맞춘 선행연구는 기 존의 오프라인 및 온라인 거래 환경과 비교하 여, 모바일거래에서 이용자가 추구하는 핵심 적인 혜택과 비용 요인이 무엇인지 밝히고자 시도하였다[35, 46]. 이러한 요인들로는 적시 성, 쉬운 접근, 장소와 시간의 상호의존성, 보 안문제, 비용 등이 제시되고 있다 $[35,46]$. 특
히, 가장 주목받은 모바일거래의 핵심 특징은 고객이 언제 어디서든지 장소와 시간의 제약 없이 기업이 제공하는 정보와 서비스를 이용 할 수 있도록 하는, 모바일 기기의 편재적인 (Ubiquitous) 특성에서 기인하는, 시간 효율성 이다. 즉, '시간'은 모바일거래에서 이용자가 고려하는 핵심 요인이다[35, 46]. 시간은 소비 자 행위에 영향을 미치는 핵심변수로서 오래 전부터 연구자들의 관심을 받아온 변수이기도 하다[7]. Tojib와 Tsarenko[56]는 모바일 서비 스의 편재적인 특성에 의해 발생하는 시간절 약을 강조하는 실용적 가치로서 시간 편의성 (Time Convenience)이라는 용어를 사용했으 며, 시간 편의성은 이용 용이성 및 즐거움보 다 지각된 가치에 더욱 영향력 있는 변수로 나타났다. Kim and Mun[33]은 DMB 모바일 서비스 이용자를 대상으로 한 연구에서 높은 시간압박감을 느끼는 이용자일수록 시간적 비 용이 증가하여 결과적으로 즐거움과 이용자 만족이 감소한다고 주장했다. 이와 더불어, 모 바일 서비스의 유비쿼터스 특성은 시간적 비 용과 이용자 만족 간의 관계를 조절한다고 주 장했다. 시간압박감은 제품 또는 서비스의 구 매 및 소비에서 요구되는 행동을 수행하기 위 해 소비자가 필요한 시간이 부족한 상태를 의 미한다[30]. 이와 같이, 스마트폰에 기반한 모 바일거래는 편재적인 특성으로 인해 소비자의 시간부족에 따른 부담감을 상당부분 감소시킬 수 있을 것이며, 이는 이용자의 시간 효율성 에 관한 가치 창출에 상당히 기여할 수 있을 것이다. 그러므로 본 연구는 모바일거래에서 이용자가 추구하는 가치의 한 차원으로 시간 적 가치를 포함하고자 한다. 


\section{3 서비스 편재성}

서비스 편재성은 모바일거래의 가장 고유한 특징으로 이용자가 시간과 장소의 제약 없이 언제 어디서나 모바일기기를 통해 인터넷에 접 속하여 실시간으로 필요한 제품, 서비스, 정보 를 이용하고 거래를 수행할 수 있도록 가능하 게 한다[32, 33, 35, 40,59]. 모바일거래는 서비스 전달의 시간적(Temporal) 및 공간적(Spatial) 제약조건을 제거하여 이용자의 지각된 가치를 증가시킨다[46]. 즉, 모바일거래는 유비쿼터스 적 연결성, 즉시접속성 등이 실현되는 거래환 경이다. 모바일거래에서 고객은 모바일 기기 와 모바일거래 어플리케이션 플랫폼과 직접적 인 상호작용을 수행 한다. 이러한 상호과정동 안에, 고객은 지각된 혜택에 대응하여 이러한 서비스를 획득하기 위해 지출한 비용을 평가 한다. 서비스 편재성은 스마트폰 기반 모바일 거래에서 매우 중요한 혜택 요인이다. 이상적인 모바일거래 환경은 고객에게 개인화된, 고객 화된, 관계에 기반한, 적시적인, 위치기반 서비 스를 전달하는 것이다[38]. 이러한 환경은 고 객과 서비스 제공자간의 상호작용을 끊이지 않고 24 시간 지속시키며, 이용자에게 풍부한 가치를 제공한다[56]. 이에, 본 연구는 서비스 편재성을 모바일거래에서 이용자의 지각된 가 치들을 증가시키는 핵심적인 모바일 특성 요 인으로 고려하고자 한다.

스마트폰의 이용으로 향상된 서비스 편재 성은 이용자에게 새로운 가치들을 창출하고, 이용자의 이용행위에도 영향을 미칠 수 있다. Tojib와 Tsarenko[56]는 서비스 편재성이 즐 거움, 이용 용이성, 시간 편의성, 지각된 가치 를 증가시키고 결과적으로 고객만족과 실제이
용의 증가로 이어진다고 제시했다. 즉, 모바일 거래의 서비스 편재성은 이용자의 시간 효율 성뿐만 아니라 다양한 실용적 혜택들과 매우 밀접하게 관련된다. 이들의 연구결과는 시간 편의성이 이용 용이성과 즐거움보다 지각된 가치에 가장 영향력 있는 변수임을 밝히고 있 다. Nysveen 등[46]은 모바일 서비스의 이용 으로 소비자가 정보와 서비스에 유비쿼터스적 인 접근과 개인화된 정보교환을 가능하게 하 여, 기업이 새로운 기회들을 창출할 수 있다 고 주장했다. Lee 등[40]은 모바일 인터넷 서 비스 품질에 관한 측정도구를 개발하면서, 유 비쿼터스적인 연결성을 상호작용 품질의 핵심 차원으로 고려하였다. 이들은 모바일 인터넷 서비스 품질을 서비스 제품(즉, 결과품질), 서 비스 전달(즉, 상호작용 품질), 서비스 환경 (즉, 서비스케이프 품질)의 세 가지 차원으로 측정하고 이들 차원은 또한 하위차원을 갖는 것으로 개념화했다.

셀프서비스 기술(Self-Service Technologies, $\mathrm{SST}$ )에 관한 연구는 종업원과의 상호작용 없 이 고객이 스스로 서비스를 선택하고 창출하 기 위해서는 편의성 요인이 매우 중요하다고 강조했다. SST는 이용자가 종업원의 직접적 인 관여 없이 스스로 서비스를 수행하는 모든 기술기반 접점을 의미한다[45]. 즉, 고객이 스 스로 서비스를 생산하는 은행의 ATM서비스, 공항의 무인 항공권발매 키오스크(Kiosk), 관 공서의 자동증명서 발급기, 온라인 쇼핑 및 뱅킹 등과 같이 다양하다[14]. 셀프 서비스 관 점에서 편의성은 고객이 SST에 의한 서비스 를 선택하고 이용하는데 요구되는 지각된 시간 과 노력으로써 정의된다[16]. 고객이 종업원의 관여 없이 서비스를 수행하는 상황에서, 편의 
성은 거래의 시작에서 완료에 이르기까지 고객 을 지원할 수 있는 상황적 요인들을 포함한다. 예를 들어, Berry 등[8]의 접근 편의성(Access Convenience)을 제시했으며, 고객의 SST 이 용노력은 SST의 물리적 위치, 운영시간, 전반 적 이용가능성에 의해 결정된다고 주장했다. Meuter 등[45]은 SST 만족이 '내가 원하는 시간'과 '내가 원하는 장소'의 요인에 의해 결 정된다고 주장했다. 유사하게, Pujari[48]는 정 보에의 접근성이 SST 이용자가 추구하는 핵심 가치라고 강조했다. Collier와 Sherrell[16]은 시간과 위치 접근성에 관한 이용자의 지각된 편의성이 SST 이용을 촉진하는 시작점이라 고 주장했다. 즉, 편의성은 이용자의 거래속 도, 새로운 정보와 기능들의 사용 촉진, 서비 스 제공자에 대한 신뢰, 지각된 가치, 이용자 만족, SST 이용에 광범위하게 영향을 미치는 핵심변수라고 제시했다. 스마트폰 기반 모바 일거래는 이용자가 스스로 필요한 서비스에 접근하여 거래의 시작에서부터 완료에 이르기 까지 모든 과정과 결과를 결정하는 대표적인 SST이다. 모바일기술에서 기인하는 서비스 편 재성은 고객이 언제 어디서든지 시간과 장소 의 제약 없이 원하는 서비스 또는 거래의 수 행을 가능하게 함으로써 SST 연구자들이 강 조해 온 편의성의 개념을 더욱 강화시켜 줄 수 있다. 그러므로 본 연구는 서비스 편재성을 이용자의 지각된 가치 증가에 영향을 미치는 모바일거래의 핵심적인 특성으로 고려한다.

\section{4 이용자 통제성}

이용자 통제성(User Control)은 모바일거래 에서 개인의 지각된 가치 및 행위의도와 관련
된 핵심 변수이다 $[35,46]$. 이용자 통제성은 서 비스 접점에서 고객이 서비스 과정이나 결과에 관하여 스스로 관리할 수 있는 통제능력을 가 지고 있다는 믿음을 의미한다[17]. Kleijnen 등[35]은 모바일 서비스 이용에서 고객의 지 각된 통제성이 지각된 가치의 평가에 영향을 주어 결과적으로 이용의도에 영향을 준다고 주장했다. Collier와 Sherrell[16]은 지각된 통 제성이 개인의 행위의도를 결정하는 다른 변 수들에 영향을 미치는 시작점으로써, 이용자 의 동기요인들(거래의 속도, 신뢰, 탐색), 소비 자 태도, SST 의도에 광범위하게 영향을 미 친다고 주장했다. 이와 같이, 이용자의 지각된 통제성은 모바일거래에서 이용행위에 직간접 으로 영향을 주는 핵심 변수로서 작용할 수 있을 것이다. 그러므로 본 연구는 지각된 통 제성을 이용자의 지각된 가치 창출에 영향을 미치는 모바일거래의 또 다른 핵심 특성으로 고려한다.

지각된 통제성은 계획된 행위이론(Theory of Planned Behavior, TPB)에서 개인의 행위 의도 및 실제행위를 예측하는 선행변수로서 제 시되었다[1]. TPB는 합리적 행위이론(Theory of Reasoned Action, TRA)[22]을 확장하여, 행위의 성공적인 수행이 개인의 통제 하에 완 전히 놓여있지 않은 상황(즉, 비자발적 행위) 을 설명하고자 시도하였다. 구체적으로, TPB 는 TRA에서 개인의 행위의도의 예측치로써 제시한 행위에 대한 태도(Attitude)와 주관적 규범(Subjective Norm)에 추가적으로 지각된 통제성을 포함했다. 지각된 통제성은 특정행 위를 수행하기가 용이한지 또는 어려운지에 관한 이용자의 지각으로 정의된다[1]. 즉, 지 각된 통제성은 행위를 수행하는 개인의 지각 
된 능력을 의미한다. $\mathrm{TPB}$ 는 지각된 통제성이 개인의 행위의도에 영향을 미치지만 이의 효 과는 약하다고 주장한다. 이러한 이유는 지각 된 통제성 자체가 행위에 참여하려는 열의를 창출하는 변수 없이는 행위의도를 이끌어 내 지 못한다고 보기 때문이다[20]. 예를 들어, 고 객이 능력을 가지고 있고 소매점으로부터 물 건을 훔칠 수 있는 기회를 가지고 있지만(즉, 통제성을 가지고 있지만), 이것이 곧 고객이 그렇게 행동한다는 것을 의미하지는 않는다.

지각된 통제성은 SST 연구에서 이용자의 $\mathrm{SST}$ 수용과 이용에 영향을 미치는 핵심 선행 변수로서 제시되었다. SST 환경에서, 지각된 통제성은 셀프서비스 접점의 프로세스와 결과 물을 결정할 수 있는 능력을 가지고 있다는 믿음을 의미한다[16]. 잘 설계된 SST를 이용 하여, 고객은 표준화된 성과를 수용하는 대신 에 자신의 능력, 욕구(Needs), 요구사항에 따 라 서비스 결과를 결정할 수 있는 능력을 가 질 수 있다. 이와 같이, 이용자는 SST를 이용 하여 거래의 속도를 높이고, 자신이 원하는 만큼의 상호작용성(Interactivity) 수준을 결정 할 수 있으며, 결과적으로 자신이 원하는 서 비스 결과물을 획득할 수 있다[17]. 하지만, 이 러한 SST의 특성은 이용자에게 강점이자 동 시에 SST 수용과 이용을 방해하는 약점으로 작용할 수 있다. 즉, 셀프서비스 경험의 패러 독스가 존재한다. 고객이 SST를 이용하여 스 스로 서비스 결과를 창출하는 과정에서 느끼 는 통제성의 부족은 고객을 좌절시킬 뿐만 아 니라 SST 이용을 중단하게 만드는 요인으로 작용할 수 있기 때문이다[18]. 이와 같이, 지각 된 통제성은 스스로 서비스 결과를 생성하는 $\mathrm{SST}$ 거래환경에서 이용행위에 영향을 미칠
수 있다[16].

이용자가 SST를 이용한 거래를 선호하는 가장 핵심적인 이유 중의 하나는 지각된 통제 성의 증가 때문이다[6, 37]. Bateson[6]은 개인 들이 금전적 절약을 위해서가 아니라 지각된 통제성 때문에 셀프 서비스 거래를 선택한다고 제시했다. Bateson과 Hui[5]은 지각된 통제성 을 증가시킴으로써, 기업은 고객의 서비스 가 치를 향상시킬 수 있다고 주장했다. Bobbit과 Dabholkar[9]은 고객이 높은 통제성을 가지고 있다고 지각하는 경우에 새로운 기술의 활용에 더욱 적극적이 된다고 주장했다. Korgaonkar 와 Wolin[36]는 온라인을 대상으로 한 연구에 서, 통제성을 추구하는 고객의 욕구가 웹 페 이지를 이용하게 만드는 가장 큰 동기요인 중 의 하나라고 밝혔다. Choi와 Lee[14]는 온라인 쇼핑을 대상으로 한 연구에서 SST 품질차원 의 한 요인으로 고객의 지각된 주도권(즉, 통 제성)을 제시하고, 지각된 주도권이 고객가치를 증가시키고 결과적으로 고객만족, 구전효과 및 재이용의도와 같은 충성도 증가와 관련되어 있 다고 주장했다. 이와 같이, 셀프 서비스 거래 환경에서 고객의 지각된 통제성은 지각된 가 치의 향상 $[5,35]$, 서비스 품질의 평가[17, 18] 등과 관련된 핵심변수이다.

\section{3. 연구모델 및 연구가설}

\section{1 연구모형}

본 연구는 스마트폰 기반 모바일거래를 통 해 이용자가 추구하는 핵심 가치들이 무엇인 지 규명하고, 이러한 핵심 가치들이 모바일거 
래의 이용에 미치는 효과를 검증한다. 구체적 으로, 본 연구는 모바일거래에서 이용자가 추 구하는 지각된 가치를 시간적 가치, 기능적 가치, 경제적 가치의 세 가지 차원으로 개념 화하고 모바일거래 이용에 미치는 효과를 규 명하고자 한다. 모바일거래는 이용자가 거래 완료를 통해 원하는 결과를 얻을 수 있는지가 가치평가의 핵심부분으로 작용한다[35]. 그러 므로 모바일거래에서 이용자는 기본적으로 기 능적(실용적) 가치에 의해 상당히 동기 부여 된다. 특히, 모바일거래는 이용자에게 시간의 절약과 효율적인 사용면에서 상당한 혜택을 제공할 수 있을 것으로 기대되며, 본 연구는 이러한 점을 시간적 가치로서 개념화하고 모 바일거래 이용에 미치는 효과를 검증하고자 한다. 마지막으로, 모바일거래는 서비스 및 거 래 수행에서 이용자의 금전적인 비용의 감소 를 통해 경제적 가치를 제공할 수 있으며, 이 는 모바일거래 이용에 영향을 미칠 것이다. 본 연구는 모바일거래에 관한 세 가지 가치 차원들이 이용행위에 미치는 개별적인 효과를 검증하고자 한다.

이와 더불어, 본 연구는 스마트폰에 기반한 모바일거래의 핵심 특성으로 서비스 편재성과 이용자 통제성을 제시하고, 이들 특성들이 이 용자의 가치증대에 기여할 수 있을 것으로 이 론화한다. 서비스 편재성은 모바일 서비스의 가장 중요한 특성이며[32, 33, 35, 40, 46], 스 마트폰에 의해 향상된 서비스 편재성은 이용 자에게 새로운 가치를 창출할 수 있을 것이 다. 스마트폰 기반 모바일거래가 종업원의 관 여 없이 이용자가 스스로 거래의 과정과 결과 를 창출하는 셀프 서비스 환경이라는 점에서, 본 연구는 이용자 통제성이 가치 증가에 영향
을 미칠 것으로 이론화한다. 지각된 통제성은 이용자가 전통적인 종업원에 의한 서비스를 선택하는 대신에 SST의 이용을 선택하는 또 다른 핵심 이유이다[16, 35]. 이상의 논의를 도 식화하면 <Figure $1>$ 과 같다.

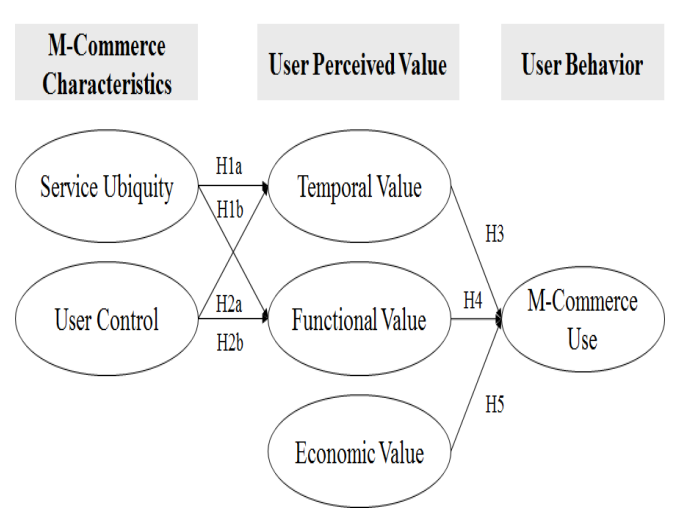

〈Figure 1〉Research Model

\section{2 연구가설}

\subsection{1 서비스 편재성과 시간적 및 기능적 가치간의 관계}

소매 상황에서 거래의 속도와 시간의 효율성은 기술이용을 통해 고객이 얻고자 하는 가장 중요 한 혜택이다[51]. 모바일거래는 이용자에게 서 비스로의 실시간 및 주문형(On-Demand) 접 근을 제공하여 이용자의 가치 향상에 기여한 다[35]. 스마트폰 기반 모바일거래에서 서비스 편재성은 기존의 인터넷거래에서보다 더욱 강화 되며, 기업은 이러한 상시적인 연결성(Connectivity)에 추가적으로 지역화(Localization) 및 고객화된 서비스 제공이 가능하다[28, 32]. 이 상적인 모바일 서비스 환경은 고객에게 개인 화된, 관계에 기반한, 적시적인, 위치기반 서 
비스를 전달하는 것이다[38]. 이러한 환경은 고객과 기업 간의 상호작용을 끊어짐 없이 24 시간 지속시키며, 이용자에게 높은 가치를 제 공한다[56]. 이와 같이, 스마트폰 기반 모바일 거래는 고객의 손끝에 달려 있으며, 고객은 필요한 시점에서 언제든지 모바일거래를 수행 할 수 있다.

스마트폰에 기인하는 서비스 편재성은 셀 프서비스 거래환경에서 이용자가 추구하는 핵 심 가치인 '빠른 거래 속도'를 가능하게 하여, 이용자의 시간적 가치를 높이는데 크게 기여 할 수 있을 것이다. Tojib와 Tsarenko[56]는 모바일 서비스의 편재적인 특성에 의해 발생 하는 시간절약을 강조하는 변수로서 시간 편 의성을 제시했으며, 시간 편의성이 이용 용이 성과 즐거움보다 소비가치를 증가시키는 핵심 변수라고 주장했다. Collier와 Sherrell[16]는 $\mathrm{SST}$ 의 시간과 장소에 관한 편리성이 지각된 거래 속도를 평가하는데 직접적인 영향을 미 치는 핵심 요인이라고 주장했다. 즉, 고객이 $\mathrm{SST}$ 의 이용으로 시간과 장소의 제약사항을 극복할 수 있는 경우에(예 : 집에서 이용 가능 하거나 또는 24 시간 서비스에 접근 가능한 경 우에), 이러한 기술이 제공하는 혜택은 고객의 이동시간을 절약해 주어, 더욱 빠른 거래를 가능하게 한다. Kleijnen 등[35]은 시간 편의 성이 모바일 서비스 전달의 가치를 증가시키 는 핵심 선행변수임을 검증하였다. 이와 같이, 스마트폰 기반 모바일거래는 종업원의 관여 없이 고객 스스로가 서비스 및 거래를 수행하 는 오늘날의 대표적인 SST 환경이며, 모바일 기술이 제공하는 편재적인 특성은 이용자가 원하는 시간과 장소에서 즉각적으로 필요한 거래를 가능하게 함으로써 이용자의 시간적
가치 증가에 크게 기여할 수 있을 것이다.

스마트폰에 기반한 서비스 편재성은 또한 이용자의 기능적 가치를 상당히 증가시킬 수 있을 것이다. 기능적 가치는 이용자가 모바일 거래의 이용결과로써 얻고자 하는 목표 및 성 과에 관한 것으로 실용적인 측면의 혜택을 의 미한다. 효율적인 그리고 적시적인 서비스 전 달은 소비자의 실용적 가치를 이끌어 낸다[12]. 이 주장은 모바일 서비스 환경에 특히 적합하 며, 모바일 서비스는 소비자가 언제 어디서든 지 거래에 관한 정보를 수집하고 실행할 수 있게 한다[4]. 쾌락적인 유비쿼터스 환경을 대 상으로 한 $\mathrm{YoO}$ 등[59]의 연구는 이용자 편재 성이 유용성을 상당히 증가시키고 있음을 보 여주었다. Jang과 Kim[31]는 유비쿼터스 서비 스의 지속이용에 관한 연구에서, 유비쿼터스 시스템적 특성차원으로 서비스 편재성을 고려 했으며, 서비스 편재성은 실용적 가치인 지각 된 유용성을 증가시키는 것으로 나타났다. 본 연구는 모바일 특성에서 기인하는 서비스 편 재성이 이용자의 기능적 가치 즉, 모바일거래 를 통해 이용자가 얻고자 하는 실용적 혜택들 에 관한 지각을 크게 증가시킬 수 있을 것으 로 가설을 설정한다.

$\mathrm{Hla}$ : 서비스 편재성은 시간적 가치에 정 $(+)$ 의 영향을 미칠 것이다.

$\mathrm{H} 1 b$ : 서비스 편재성은 기능적 가치에 정 $(+)$ 의 영향을 미칠 것이다.

\section{2 .2 이용자 통제성과 시간적 및 기능적 가치 간의 관계}

서비스 접점에서 서비스 과정과 결과를 고 객이 선택하고 관리할 수 있는 능력을 가리키 
는 이용자 통제성은 모바일거래를 선택하는 핵심적인 혜택으로 제시되었으며[6, 37], 이용 자의 지각된 가치 형성에 영향을 미치는 변수 로 제시되었다[35, 46]. SST 이용 상황에서, 고객이 거래를 완수하기 위해 어떠한 내용들 과 단계들을 진행해야 하는지 이해하고 통제 할 수 있는 경우에, 거래를 수행하는데 소요 되는 시간은 감소될 것이다[16]. 즉, 통제성이 높은 고객은 거래를 완수하기 위해 필요한 단 계들을 수행하는데 통제성이 낮은 고객보다 필요한 메뉴옵션들로 빨리 이동할 수 있어 거 래를 효율적으로 수행할 수 있을 것이다[16]. Collier와 Sherrell[16]은 SST 이용 상황에서, 고객의 지각된 통제성이 높은 경우에 거래의 속도가 증가하고 결과적으로 SST 이용의도 가 증가한다고 밝히고 있다. 이와 같이, 통제 성이 높은 고객은 모바일거래에서 스스로 거 래시점, 거래내용, 거래순서를 이해하고 관리 함으로써 필요한 시점에서 거래를 완료할 수 있다. 그러므로 이용자 통제성은 모바일거래 를 빠른 거래를 가능하게 하여 이용자의 시간 적 가치 증대에 기여할 수 있을 것이다.

이와 더불어, 이용자 통제성은 기능적 가치 의 증가와도 관련될 수 있다. 이용자 통제성 은 자신의 목표달성 과정에 영향을 줄 수 있 으며 결과적으로 획득 가능한 성과에 영향을 미칠 수 있다[5]. 즉, 통제성이 높은 이용자는 자신이 거래과정을 효과적으로 관리함으로써 원하는 성과를 창출할 수 있다고 지각한다. Kleijnen 등[35]은 모바일거래에서 이용자 통제 성이 거래에 관한 지각된 가치를 증가시키고 결과적으로 이용의도를 증가시킨다고 제시했 다. 이와 같이, 이용자가 스스로 거래의 과정 과 결과를 선택하는 모바일거래에서 이용자가
높은 통제성을 보유할수록 거래를 성공적으로 완수하고 이를 통해 원하는 성과를 얻을 수 있을 것이다. 그러므로 본 연구는 이용자 통 제성이 증가할수록 기능적 가치가 증가할 것 으로 가설을 설정한다.

$\mathrm{H} 2 \mathrm{a}$ : 이용자 통제성은 시간적 가치에 정 $(+)$ 의 영향을 미칠 것이다.

$\mathrm{H} 2 \mathrm{~b}$ : 이용자 통제성은 기능적 가치에 정 $(+)$ 의 영향을 미칠 것이다.

\subsection{3 시간적 가치와 모바일거래 이용}

모바일거래의 이용으로부터 고객이 추구하 는 대표적인 혜택 중의 하나로써 가장 많이 언급되고 있는 것이 시간 효율성 측면이다[35, 46]. 즉, 모바일거래에서 이용자가 고려하는 핵심요인이 '시간'이다. Nysveen 등[46]은 고 객이 시간과 장소의 제약 없이 서비스의 이용 이 가능하게 하는 모바일 기기의 유비쿼터스 적인 특성이 시간 효율성의 증가에 기여한다 고 주장했다. Shankar 등[52]은 모바일 가치 창출의 핵심이 이동성(Mobility)에 있으며, 이 동성은 이용자가 다른 채널들과 비교하여 보다 경제적으로 자신의 소비목표들을 달성할 수 있 도록 한다고 주장했다. 소매 상황에서, 시간 편의성에 관한 혜택은 서비스 획득을 촉진하며, 이는 시간에 민감한 서비스들(Time-Critical Services)에서 특히 중요하다[29]. 즉, 한정된 여행상품, 마지막 예약기회, 주문 상태 추적, 재고량 파악 등과 같은 시간이 중요한 서비스 에서 시간적 가치가 증가하며, 이는 모바일거 래의 이용을 촉진한다. 이와 같이, 빠른 거래 의 수행, 시간의 절약 등이 강조하는 모바일 거래 상황에서 시간적 가치는 모바일거래의 
이용을 증가시키는 핵심 선행변수로서 작용할 것이다.

$\mathrm{H} 3$ : 시간적 가치는 모바일거래 이용에 정 $(+)$ 의 영향을 미칠 것이다.

\subsection{4 기능적 가치와 모바일거래 이용}

제품 또는 서비스 이용의 결과로써 얻는 성 과부분에 관한 효용을 의미하는 기능적 가치 는 모바일거래 이용을 증가시키는 핵심 선행 변수로서 작용할 수 있을 것이다. 유사하게, TAM은 IS 이용의 외재적 동기요인으로 지각 된 유용성을 강조했다[19]. 지각된 유용성은 IS 이용이 자신의 과업성과를 향상시킬 것이 라는 믿음을 의미하며, IS 이용의 결과로써 이용자가 추구하는 대표적인 실용적 가치를 반영하는 변수이다[19]. 기능적 가치는 다양한 모바일 서비스 이용 상황에서 개인의 행위에 영향을 미치는 것으로 제시되었다. 예를 들어, Turel 등[58]은 모바일 SMS의 수용을 결정하 는 핵심변수로서 지각된 가치를 제시하고, 지 각된 가치는 성과/품질가치(즉, 기능적 가치), 정서적 가치, 금전적 가치, 사회적 가치의 네 가지 가치에 의해 결정된다고 주장했다. SNS 의 지불의도에 관한 연구에서, $\mathrm{Lu}$ 와 $\mathrm{HsiaO}$ [43]은 이용자의 지각된 가치가 만족과 지불 행위의도에 직접적인 영향을 미치며, 지각된 가치는 성과/품질가치(즉, 기능적 가치), 정서 적 가치, 사회적 가치, 금전적 가치의 네 가지 가치에 의해 형성된다고 주장했다. $\mathrm{Kim}$ 등 [34]은 소셜 네트워킹 커뮤니티에서 기능적 가치, 정서적 가치, 사회적 가치가 디지털 아 이템 구매의도에 적집적인 영향을 미칠 것으 로 가설화했다. 이와 같이, 이용자 가치에 관
한 연구는 기능적 가치를 전반적 가치 형성의 핵심 결정요인으로 또는 이용자 행위(의도)를 결정하는 핵심 선행변수로서 주장했다. 그러 므로 본 연구는 모바일거래를 통해 이용자가 획득 가능한 실용적 혜택들이 많다고 지각할 수록 모바일거래의 이용은 증가할 것으로 가 설을 설정하였다.

$\mathrm{H} 4$ : 기능적 가치는 모바일거래 이용에 정 (+)의 영향을 미칠 것이다.

\section{2 .5 경제적 가치와 모바일거래 이용}

경제적 가치는 금전적 측면을 강조하는 이 용자의 가치 유형이다. 경제적 가치는 인터넷 또는 모바일 금융서비스 이용과정에서 부과된 서비스 요금 또는 이용료가 이러한 서비스를 통해 획득하는 혜택에 의해 상쇄되는가를 의 미한다[28]. Lee 등[42]은 모바일 금융 서비스 의 이용의도에 영향을 미치는 변수들에 관한 연구에서, 금전적 가치와 연결성이 이용의도 에 직접적인 영향을 미치지는 못하고 지각된 유용성과 이용 용이성에 영향을 주어 결과적 으로 이용의도를 증가시키는 것으로 나타났다. Lee 등[39]은 UTAUT 모형을 적용하여 스마 트폰 이용자의 앱북 구매의도를 연구한 결과, 금전적 및 감정적 비용을 포함하는 비용요인 이 이용자의 구매행위를 증가시키고 있음을 확인하였다. 선행연구는 경제적 가치가 이용 자의 전반적 가치 형성에 영향을 주어 결과적 으로 이용자 행위에 영향을 미치거나 $[43,57$, 58] 또는 경제적 가치가 이용자 행위 및 행위 의도에 직접적으로 영향을 준다고 주장했다 [34, 39, 61]. 본 연구는 모바일거래에서 이용 자가 부담하는 가격이 적절하다고 지각할수록 
모바일거래 이용은 증가할 것으로 기대한다. 반대로, 이용자가 모바일거래를 위해 지불하 는 가격과 비교하여 얻는 혜택이 낮다고 지각 하는 경우에는 모바일거래의 이용은 감소할 것이다. 이에 따라, 본 연구는 다음의 가설을 설정한다.

$\mathrm{H} 5$ : 경제적 가치는 모바일거래 이용에 정 $(+)$ 의 영향을 미칠 것이다.

\section{4. 연구방법 및 연구결과}

\section{1 변수의 조작적 정의 및 측정}

본 연구에서 사용된 변수의 조작적 정의, 측정항목, 관련문헌들은 < Table $1>$ 에 제시하 였다. 모든 설문항목은 선행연구에서 검증된 항목들을 본 연구 상황에 맞게 수정하여 사용 하였으며, 리커트형 7점 척도를 이용하여 1점 은 “전혀 그렇지 않다”로, 7점은 “매우 그렇 다"로 측정하였다.

\section{2 데이터 수집 및 표본 특성}

자료 수집은 스마트폰을 이용하여 모바일 뱅킹, 모바일 쇼핑, 모바일 티켓팅(버스표/기 차표 구매)의 모바일거래를 이용해 본 경험이 있는 $\mathrm{C}$ 대학의 대학재학생과 대학원생을 대상 으로 인터넷 설문을 이용하여 대략 1 개월 동 안 진행되었다. 인터넷 설문의 결과 총 196 개 가 회수되었다. 이 중에서 설문을 시작했으나 중도에 포기한 26개 데이터와 설문에 응답을 마쳤으나 미응답이 많은 설문지 6개를 제거하
여 164 개가 최종적으로 분석에 이용되었다.

자료분석은 PLS(Partial Least Squares)을 이용하여 측정모형 분석(즉, 확인적 요인분석) 과 구조모형 분석을 수행하였다. PLS 프로그 램은 Smart PLS 2.0을 이용하였다. PLS가 사 용되는 주요 이유는 샘플의 규모가 작은 경우, 데이터가 비정규분포를 이루고 있는 경우, 연구에 사용된 측정치가 조형지표(Formative Measures) 인 경우, 예측에 초점을 맞추고자 하는 경우, 모델이 복잡한 경우 순으로 나타났다[49]. 본 연구는 샘플의 수가 164 개로 크지 않고, SPSS 에서 Kolmogorov-Smirnov와 Shapiro-Wilk 의 정규성 검정결과에서도 모든 연구변수의 유의확률 값이 유의수준 0.05 보다 작은 것으 로 나타났다. 그러므로 데이터가 정규분포라 는 귀무가설이 기각되어 데이터가 정규분포를 따르지 않음을 의미한다. 이에 따라, 본 연구 는 정규분포를 가정하는 Lisrel를 이용한 구조 방정식 모델 분석보다는 PLS를 이용한 구조 방정식 모델을 선택하였다.

분석에 이용된 164 개 데이터에서, 남성은 47명(28.7\%)이고 여성은 117명(71.3\%)으로 나 타났다. 연령별로는 '20대’가 149명으로 90.9\% 를 차지하고 있어 샘플의 대다수를 차지하는 것으로 나타났다. 스마트폰을 이용하여 현재 가장 많이 이용하는 모바일거래를 다중 선택 하게 한 결과, 유효응답자의 약 $71 \%$ 가 '모바 일 뱅킹'을 선택하였으며, 다음으로 응답자의 $64 \%$ 가 '모바일 쇼핑'을 응답자의 $22 \%$ 가 '기차 표/버스표 구입'을 이용하는 것으로 나타났다.

\subsection{PLS 측정 모형의 평가}

본 연구에서 사용한 측정도구에 대한 신뢰 


\section{$\langle$ Table 1〉Measurement Items}

\begin{tabular}{|c|c|c|}
\hline Constructs & Operationalization and Items & References \\
\hline $\begin{array}{l}\text { Service } \\
\text { Ubiquity }\end{array}$ & $\begin{array}{l}\text { - The extent to which users conduct smartphone-based } m \text {-commerce anytime and } \\
\text { anywhere, irrespective of time and space, accessing to necessary information and } \\
\text { service } \\
\text { (1) I can use smartphone-based } m \text {-commerce anytime. } \\
\text { (2) I can use smartphone-based } m \text {-commerce while on the road. } \\
\text { (3) I can use smartphone-based } m \text {-commerce anywhere. } \\
\text { (4) I expect that smartphone-based } m \text {-commerce would be available to use whenever I } \\
\text { need it. }\end{array}$ & {$[40,42,56]$} \\
\hline $\begin{array}{l}\text { User } \\
\text { Control }\end{array}$ & $\begin{array}{l}\text { The extent to which users can determine the details (such as the pace of } \\
\mathrm{m} \text {-commerce or the nature of information flow) of smartphone-based } \mathrm{m} \text {-commerce on } \\
\text { my own. } \\
\text { (1) Using smartphone-based } \mathrm{m} \text {-commerce allows me to make a lot of decisions on my } \\
\text { own. } \\
\text { (2) I have a lot to say about what happens during the smartphone-based m-commerce. } \\
\text { (3) I have flexibility when using smartphone-based } m \text {-commerce. } \\
\text { (4) I have control over the smartphone-based } m \text {-commerce when using the mobile } \\
\text { channel. }\end{array}$ & {$[16,35]$} \\
\hline $\begin{array}{l}\text { Temporal } \\
\text { Value }\end{array}$ & $\begin{array}{l}\text { - The extent to which users perceive that smartphone-based } \mathrm{m}^{-} \text {commerce offers the } \\
\text { utility derived from time convenience } \\
\text { (1) Using smartphone-based } \mathrm{m}^{-} \text {-commerce is an efficiency way to mange my time. } \\
\text { (2) Using smartphone-based } \mathrm{m}^{-} \text {-ommerce would be convenient for me. } \\
\text { (3) Using smartphone-based } \mathrm{m}^{-} \text {-commerce would allow me to save my time. } \\
\text { (4) Using smartphone-based } \mathrm{m}^{-} \text {-commerce would make transactions less time } \\
\text { consuming. }\end{array}$ & {$[35,56]$} \\
\hline $\begin{array}{c}\text { Functional } \\
\text { Value }\end{array}$ & $\begin{array}{l}\text { - The extent to which users perceive that smartphone-based } m \text {-commerce offers the } \\
\text { utility derived from high levels of performance or goal-attainments } \\
\text { (1) Using smartphone-based } m \text {-commerce enables me to obtain appropriate outcomes. } \\
\text { (2) Smartphone-based } m \text {-commerce offers overall excellence. } \\
\text { (3) Smartphone-based } m \text {-commerce offers satisfactory quality. } \\
\text { (4) Smartphone-based } m \text {-commerce offers reliable outcomes. }\end{array}$ & {$[34,54]$} \\
\hline $\begin{array}{c}\text { Economic } \\
\text { Value }\end{array}$ & $\begin{array}{l}\text { The extent to which users perceive that smartphone-based } \mathrm{m}^{-} \text {-commerce offers the } \\
\text { price utility derived from the efficient use of money. } \\
\text { (1) The price of products or service in smartphone-based } \mathrm{m} \text {-commerce are generally } \\
\text { resonable. } \\
\text { (2) Overall, I am happy with the price of products or service in smartphone-based } \\
\mathrm{m} \text {-commerce. } \\
\text { (3) The price of products or service in smartphone-based } \mathrm{m} \text {-commerce is appropriate } \\
\text { given its benefits. }\end{array}$ & {$[34,44,57]$} \\
\hline $\begin{array}{c}\text { M- } \\
\text { Commerce } \\
\text { Use }\end{array}$ & $\begin{array}{l}\text { - The extent to which users conduct smartphone-based } m \text {-commerce } \\
\text { (1) I widely use smartphone-based } m-\text {-commerce. } \\
\text { (2) I frequently use smartphone-based } m^{-} \text {commerce. }\end{array}$ & [11] \\
\hline
\end{tabular}


$\langle$ Table 2〉 Demographics

\begin{tabular}{|c|c|c|}
\hline \multicolumn{2}{|c|}{ Category } & Frequency \\
\hline Gender & $\begin{array}{l}\text { Male } \\
\text { Female }\end{array}$ & $\begin{array}{c}47(28.7) \\
117(71.3)\end{array}$ \\
\hline Age & $\begin{array}{l}\text { Twenties } \\
\text { Thirties } \\
\text { Over Forties }\end{array}$ & $\begin{array}{c}149(90.9) \\
9(5.5) \\
6(3.7)\end{array}$ \\
\hline $\begin{array}{l}\text { Duration of } \\
\text { Smartphone } \\
\text { Usage }\end{array}$ & $\begin{array}{l}\text { Less than one year } \\
\text { One year to less } \\
\text { than two years } \\
\text { Two years to less } \\
\text { than three years } \\
\text { More than three } \\
\text { years }\end{array}$ & $\begin{array}{c}15(9.1) \\
43(26.2) \\
67(40.9) \\
39(23.8)\end{array}$ \\
\hline $\begin{array}{l}\text { Types of } \\
\text { Smartphone- } \\
\text { based M- } \\
\text { Commerce }\end{array}$ & $\begin{array}{l}\text { Mobile Banking } \\
\text { Mobile Ticketing } \\
\text { Mobile Shopping }\end{array}$ & $\begin{array}{l}71(45.2) \\
22(14.0) \\
64(40.8)\end{array}$ \\
\hline
\end{tabular}

성 및 타당성 분석을 위해 Ringle 등[50]이 개 발한 Smart PLS 2.0을 이용한 확인적 요인분 석을 실시하였으며, Fornell과 Lacker[23]이 제 시한 기준치에 의해 평가하였다. 동일개념을 다시 측정하였을 때 동일하거나 유사한 값을 얻게 될 가능성을 의미하는 신뢰성은 크론바하 알파 값으로 평가하였으며, 분석결과는 모든 연구변수들의 알파 값이 권장치인 0.7 을 넘어서
는 것으로 나타나 연구변수의 신뢰성이 확인되 었다. 이와 더불어, 조합신뢰성(Composite Reliability)의 값이 권장치 값인 0.7 보다 높게 나타 나 연구변수들의 신뢰성이 확인되었다(<Table 4> 참조).

연구변수의 개념타당성은 모든 요인 적재값 이 0.7 이상으로 높게 나타났으며, 각 측정항목 의 요인 적재값이 교차요인 적재값보다 높게 나타났다(<Table 5> 참조), 이와 더불어, AVE (Average Variance Extracted) 값이 기준치 0.5보다 높게 나타나 연구변수의 집중타당성

〈Table 4〉 Measurement Model Assessment

\begin{tabular}{l|c|c|c}
\hline Constructs & AVE & $\begin{array}{c}\text { Composite } \\
\text { Reliability }\end{array}$ & $\begin{array}{c}\text { Cronbach's } \\
\mathrm{a}\end{array}$ \\
\hline $\begin{array}{l}\text { Service } \\
\text { Ubiquity }\end{array}$ & 0.892 & 0.970 & 0.959 \\
\hline $\begin{array}{l}\text { User } \\
\text { Control }\end{array}$ & 0.800 & 0.941 & 0.916 \\
\hline $\begin{array}{l}\text { Temporal } \\
\text { Value }\end{array}$ & 0.879 & 0.956 & 0.931 \\
\hline $\begin{array}{l}\text { Functional } \\
\text { Value }\end{array}$ & 0.877 & 0.955 & 0.930 \\
\hline $\begin{array}{l}\text { Economic } \\
\text { Value }\end{array}$ & 0.873 & 0.954 & 0.928 \\
\hline $\begin{array}{l}\text { M- } \\
\text { Commerce } \\
\text { Use }\end{array}$ & 0.959 & 0.979 & 0.958 \\
\hline
\end{tabular}

〈Table 3〉 Descriptive Statistics, Inter-construct Correlations and Discriminant validity

\begin{tabular}{c|l|c|c|c|c|c|c|c|c}
\hline \multicolumn{2}{c|}{ Constructs } & Mean & SD & A & B & C & D & E & F \\
\hline A & Service Ubiquity & 5.33 & 1.51 & 0.944 & & & & & \\
\hline B & User Control & 4.90 & 1.15 & 0.622 & 0.894 & & & & \\
\hline C & Temporal Value & 5.44 & 1.27 & 0.681 & 0.575 & 0.937 & & & \\
\hline D & Functional Value & 4.64 & 1.15 & 0.379 & 0.437 & 0.416 & 0.936 & & \\
\hline E & Economic Value & 4.20 & 1.12 & 0.395 & 0.517 & 0.382 & 0.294 & 0.935 & \\
\hline F & M-Commerce Use & 4.38 & 1.81 & 0.613 & 0.542 & 0.514 & 0.474 & 0.404 & 0.980 \\
\hline
\end{tabular}

Note : Values along the diagonal indicate the square root of the AVE. SD : Standard Deviation. 
$\langle$ Table 5〉Item Loadings and Cross-Factor Loadings

\begin{tabular}{c|c|c|c|c|c|c}
\hline Constructs & $\begin{array}{c}\text { Service } \\
\text { Ubiquity }\end{array}$ & $\begin{array}{c}\text { User } \\
\text { Control }\end{array}$ & $\begin{array}{c}\text { Temporal } \\
\text { Value }\end{array}$ & $\begin{array}{c}\text { Functional } \\
\text { Value }\end{array}$ & $\begin{array}{c}\text { Economic } \\
\text { Value }\end{array}$ & $\begin{array}{c}\text { M-Commerce } \\
\text { Use }\end{array}$ \\
\hline ubiq1 & 0.939 & 0.595 & 0.642 & 0.393 & 0.375 & 0.614 \\
\hline ubiq2 & 0.944 & 0.579 & 0.626 & 0.296 & 0.397 & 0.559 \\
\hline ubiq3 & 0.962 & 0.597 & 0.632 & 0.371 & 0.383 & 0.579 \\
\hline ubiq4 & 0.931 & 0.578 & 0.671 & 0.367 & 0.340 & 0.560 \\
\hline cont1 & 0.619 & 0.904 & 0.553 & 0.414 & 0.493 & 0.515 \\
\hline cont2 & 0.576 & 0.897 & 0.459 & 0.426 & 0.487 & 0.537 \\
\hline cont3 & 0.540 & 0.921 & 0.555 & 0.420 & 0.448 & 0.475 \\
\hline cont4 & 0.481 & 0.854 & 0.480 & 0.289 & 0.420 & 0.406 \\
\hline time2 & 0.673 & 0.578 & 0.939 & 0.455 & 0.395 & 0.536 \\
\hline time3 & 0.620 & 0.504 & 0.938 & 0.340 & 0.329 & 0.409 \\
\hline time4 & 0.619 & 0.529 & 0.936 & 0.365 & 0.344 & 0.489 \\
\hline function1 & 0.373 & 0.421 & 0.422 & 0.956 & 0.278 & 0.489 \\
\hline function2 & 0.385 & 0.404 & 0.405 & 0.955 & 0.269 & 0.465 \\
\hline function3 & 0.300 & 0.403 & 0.335 & 0.897 & 0.283 & 0.366 \\
\hline price1 & 0.377 & 0.482 & 0.396 & 0.233 & 0.908 & 0.338 \\
\hline price2 & 0.371 & 0.470 & 0.345 & 0.285 & 0.954 & 0.377 \\
\hline price3 & 0.362 & 0.498 & 0.336 & 0.302 & 0.941 & 0.413 \\
\hline use1 & 0.598 & 0.554 & 0.499 & 0.480 & 0.405 & 0.980 \\
\hline use2 & 0.603 & 0.508 & 0.507 & 0.447 & 0.387 & 0.979 \\
\hline$:$ An & & & & & \\
\hline
\end{tabular}

Note : An item(time1) was eliminated during the CFA because its loading on its corresponding construct was below the 0.7 threshold.

이 확인되었다(<Table $4>$ 참조). 연구변수의 판별타당성은 $\mathrm{AVE}$ 의 제곱근 값이 모든 연구 변수의 상관관계 값보다 높게 나타나, 판별타 당성이 충족되었다(<Table $3>$ 참조).

\subsection{PLS 구조모형 평가 및 가설검정}

본 연구의 가설들을 검증하기 위해 PLS 구 조모형(Structural Model or Inner Model)의 경로계수를 이용하였다. 경로계수의 통계적 유 의성 평가는 부트스트랩(Bootstrapping) 방법을 이용하였으며, 부트스트랩 표본은 1000 개로
설정하였다. 구조모형의 검증결과는 < Table $6>$ 에 제시되었고, 연구가설의 검정결과는 <Figure 2>에 제시되었다.

구조모형의 평가기준으로는 일반적으로 내 생변수의 $R^{2}$ 값을 많이 이용한다. Chin[13]은 $R^{2}$ 값의 효과 정도는 상(0.26 이상), 중(0.13 $0.26)$, 하(0.02 0.13)로 평가된다. 본 연구결과 는 시간적 가치의 $R^{2}$ 값이 0.501 , 기능적 가치 의 $R^{2}$ 값이 0.210 , 모바일거래 이용의 $R^{2}$ 값이 0.379으로 모두 높게 나타났다. 이 결과는 본 연구모형의 설명력이 우수함을 뒷받침해 준다.

구조모형을 평가하는 또 다른 방법으로 Ten- 
$\langle$ Table 6〉 Structural Model Assessment

\begin{tabular}{l|c|c|c}
\hline Constructs & $R^{2}$ & $\begin{array}{c}\text { Cross }^{-} \\
\text {validated } \\
\text { Communality }\end{array}$ & $\begin{array}{c}\text { Cross }^{-} \\
\text {validated } \\
\text { Redundancy }\end{array}$ \\
\hline $\begin{array}{l}\text { Service } \\
\text { Ubiquity }\end{array}$ & na & 0.788 & na \\
\hline $\begin{array}{l}\text { User } \\
\text { Control }\end{array}$ & na & 0.650 & na \\
\hline $\begin{array}{l}\text { Temporal } \\
\text { Value }\end{array}$ & 0.501 & 0.705 & 0.425 \\
\hline $\begin{array}{l}\text { Functional } \\
\text { Value }\end{array}$ & 0.210 & 0.706 & 0.176 \\
\hline $\begin{array}{l}\text { Economic } \\
\text { Value }\end{array}$ & na & 0.694 & na \\
\hline $\begin{array}{l}\text { M- } \\
\text { Commerce } \\
\text { Use }\end{array}$ & 0.379 & 0.701 & 0.344 \\
\hline
\end{tabular}

Note : na : not applicable.

enhaus 등[55]이 제시한 $\mathrm{GoF}$ (Global Goodnessof-Fit)가 있다. GoF는 모든 내생변수의 평균 communality와 평균 $R^{2}$ 의 기하평균으로 계산 된다. $\mathrm{GoF}$ 는 최소 0.1 에서 1 이내의 값을 가지 며, 상(0.36 이상), 중(0.25 0.36), 하(0.1 0.25) 로 구분된다. 본 연구에서 $\mathrm{GoF}$ 의 값이 0.565 로 나타나 연구모형의 설명력이 매우 우수함 을 지지해 준다.

\section{5. 결 론}

\section{1 결과논의 및 연구의 시사점}

본 연구는 스마트폰 기반 모바일거래 상황 에서 이용자가 추구하는 핵심 가치를 파악하 고 이러한 가치의 증가에 기여하는 모바일거 래 특성들을 규명하고자 시도하였다. 모바일
거래는 이용자가 서비스 이용과정에서 재미와 즐거움을 추구하는 쾌락적 이용환경과는 대조 적으로 거래목표와 성과가 강조되는 실용적 이용환경이다. 그러므로 오늘날 스마트폰 기 반 모바일거래를 통해 이용자가 추구하는 핵 심 가치는 쾌락적 이용환경에서와는 차이가 존재할 것이다. 하지만, 모바일 서비스를 대상 으로 한 대다수 선행연구는 쾌락적 이용환경 에 초점을 두고 이용자의 핵심 가치들을 파악 하였다. 상대적으로, 모바일거래와 같이 목적 지향적인 이용환경에서 이용자가 추구하는 핵 심 가치에 관하여는 경험적 연구가 부족한 상 황이다. 이와 더불어, 모바일거래에서 이용자 가 중요시 하는 모바일 고유의 혜택은 무엇이 며, 이러한 혜택이 이용자의 가치 창출에 미 치는 효과에 관하여는 이해가 부족하다. 본 연구는 스마트폰 기반 모바일거래 이용자들을 대상으로 모바일거래에 고유한 핵심특성들을 도출하고 이러한 특성들이 어떻게 이용자의 다 양한 가치들과 관련되어 있는지를 규명하였다 는 점에서 학문적 시사점이 크다고 할 수 있다.

본 연구결과에 관한 구체적인 논의는 다음 과 같다. 첫째, 본 연구에서 모바일거래의 핵 심 특성으로 고려한 서비스 편재성은 이용자 의 시간적 가치를 크게 증가시키는 반면 기능 적 가치에는 비유의적인 것으로 나타났다. 이 결과는 스마트폰 기반 모바일거래를 통해 시 간과 장소의 제약 없이 언제 어디서든지 인터 넷에 접속하여 실시간으로 필요한 제품 또는 서비스를 이용하고 거래의 수행이 가능하도록 하는 서비스 편재성이 이용자의 시간적 가치 를 창출하는데 매우 영향력 있는 변수임을 제 시한다 $(\beta=0.528)$. 즉, 스마트폰 기반 모바일 거래를 이용하는 고객은 거래에 소요되는 시 


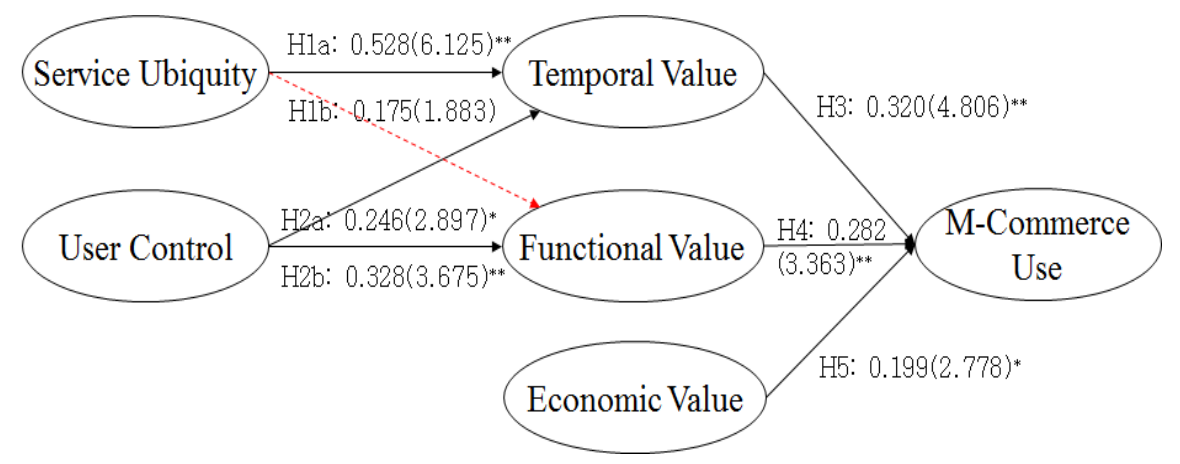

Note : ${ }^{*} p<0.01,{ }^{* *} p<0.001$.

〈Figure 2〉 Results for Structural Model and Hypothesis Testing

간에 상당한 가치를 부여하고 있음을 의미한다. 스마트폰 기반 모바일거래에 의해 더욱 강화 된 유비쿼터스적인 연결과 즉시적인 접속은 이용자의 시간적 가치를 충족시키기에 충분하 다. 그러므로 기업은 스마트폰 기반 모바일거 래를 통해 고객과의 상시적으로 연결이 가능 하며, 이는 고객에게 시간과 관련된 새로운 혜택들을 제공할 수 있는 기회들을 더욱 창출 할 수 있을 것이다. 예를 들어, Hourahin과 Howard[29]는 시간에 민감한 서비스들 예를 들어, 한정된 여행상품, 마지막 예약기회, 주 문 상태 추적, 재고량 파악 등은 시간이 중요 하게 작용하는 서비스들로써, 시간적인 측면 의 혜택들이 이용자의 소비를 촉진한다고 주 장했다. 이와 같이, 본 연구는 이용자가 모바 일거래를 통해 추구하는 핵심 가치 중의 하나 가 시간적 가치임을 제시함으로써 모바일거래 를 통해 기업이 우선적으로 시간효율성을 추 구하는 고객에게 적절한 전략을 개발하는 것 이 필요함을 시사한다.

서비스 편재성이 시간적 가치를 크게 증가 시키는 반면에 기능적 가치에는 영향력이 없 는 것으로 나타났다. 기능적 가치는 이용자가
모바일거래의 결과로써 얻고자 하는 성과에 관한 것으로 실용적인 측면의 혜택을 의미한다. 이 결과는 모바일거래의 서비스 편재성이 이 용자의 목표달성을 반드시 보장하는 것은 아 님을 시사한다. 그러므로 기업은 모바일거래 를 통해 이용자가 얻고자 하는 목표들이 무엇 인지 정확히 파악하고 이를 제공하려는 노력 이 필요하다.

둘째, 본 연구에서 모바일거래의 또 다른 핵심특성으로 고려한 이용자 통제성은 시간적 가치와 기능적 가치를 모두 증가시키는 것으 로 나타났다. 이용자 통제성은 스마트폰 기반 모바일거래에서 이용자가 스스로 상호작용기 술을 이용하여 거래의 시작에서부터 완료에 이르기까지 관련 기능들을 이용할 수 있는 능 력을 의미한다. 스마트폰 기반 모바일거래 이 용에서 통제성이 높은 고객은 거래에 필요한 기능들을 잘 활용하여 빠르게 거래를 수행할 수 있을 뿐만 아니라 자신이 원하는 성과를 얻을 수 있다. 잘 설계된 모바일거래는 이용 자가 종업원이 제공하는 서비스를 수용하는 대신에 자신의 능력, 욕구(Needs), 요구사항에 따라 자유롭게 원하는 서비스를 선택하고 결 
정할 수 있다. 그러므로 기업은 이용자가 스 마트폰 기반 모바일거래를 수행하는 동안에 어떠한 단계들이 있으며 각 단계들을 이용자 가 이해하고 관리할 수 있도록 명확하게 설계 하여, 이용자의 지각된 통제성을 높임으로써 이용자의 가치를 향상시킬 수 있을 것이다. 이용자 통제성은 고객이 종업원의 관여 없이 스스로 서비스나 거래를 창출하는 SST를 선 택하는 핵심 이유 중의 하나로 주목받았던 변 수이다[6, 37]. 오늘날 많은 고객이 종업원과 의 직접적인 상호작용 없이 스스로 원하는 서 비스를 창출하는 셀프 서비스를 선호한다. 이 는 SST의 이용을 선호하는 고객들이 '시간'에 많은 가치를 부여하고 인적접촉을 최소화하여 빠른 결과를 얻고자 희망하기 때문이다[16]. 무엇보다도 SST 환경에서 고객은 자신이 원 하는 성과를 스스로 결정할 수 있기 때문이 다. 본 연구결과는 스마트폰 기반 모바일거래 에서 이용자가 스스로 거래를 주도할 수 있는 이용자 통제성에 의해 시간적 및 기능적 가치 들이 크게 증가함을 보여준다. 그러므로 기업 은 스마트폰 기반 모바일거래에서 이용자에게 거래의 주도권을 넘겨줌으로써 즉, 지각된 통 제성을 증가시킴으로써 이용자의 시간적 및 기능적 가치들을 충족시킬 수 있을 것이다.

셋째, 본 연구는 스마트폰 기반 모바일거래 의 이용이 시간적, 기능적, 경제적 가치의 실 용적 가치들에 의해 결정됨을 제시한다. 이 결과는 기존연구와도 일치한다. IS 연구자들 은 개인의 IS 이용이 과업지향적인 경우에는 목표달성 및 성과기대를 추구하는 외재적 가 치(즉, 지각된 유용성)에 의해 크게 영향을 받 지만[19], IS 이용자체의 경험에서 재미와 즐 거움을 추구하는 쾌락적 IS 이용 상황에서는
내재적 가치(즉, 지각된 즐거움)에 의해 동기 부여 된다고 제시했다[34, 41, 60, 61]. 모바일 서비스에 관한 선행연구들에서도 개인행위가 모바일 SNS, 모바일 오락서비스와 같이 쾌락적 $\mathrm{IT}$ 의 이용 상황에서는 사회적, 정서적 가치와 같은 비-기능적 가치(Non-Functional Value) 에 의해 더욱 동기 부여되며[34, 57, 58], 이용 성과, 보상 등의 실용적 혜택을 강조하는 모바 일거래 상황에서는 기능적 가치에 의해 더욱 동 기 부여됨을 밝히고 있다[[21, 46]. 예를 들어, $\mathrm{Kim}$ 등[34]은 소셜 네트워킹 커뮤니티를 대상 으로 한 연구에서, 디지털 아이템의 구매의도 에 정서적 가치(예 : 즐거움) 및 사회적 가치(예 : 사회적 관계지원)가 유의적인 반면에 기능적 가치(예 : 성과품질가치, 가격가치)는 비유의적 인 결과를 제시하면서, 디지털 아이템이 실용 적 목적보다는 쾌락적 목적을 반영하는 제품 으로 기능적 가치보다는 쾌락적 가치들에 의 해 이용자의 행위가 주도된다고 제시했다. 하 지만, 본 연구결과는 실용성을 추구하는 모바 일거래 상황에서 시간적, 기능적, 경제적 가치 와 같이 외재적 가치들에 의해 개인의 행위가 주도될 수 있음을 규명하였다는 점에서 중요 성을 지닌다. 즉, 기존의 쾌락적 상황을 강조 한 선행연구들과는 달리 실용적 상황에서 이 용자의 핵심 가치를 제시하였다는 점에서 학 문적 시사점을 지닌다. 이와 더불어, 본 연구 는 기업이 모바일거래를 통해 이용자가 추구 하는 실용적 측면의 가치들을 증가시키려는 노력이 필요함을 제시한다.

특히, 본 연구결과는 시간적 가치가 모바일 거래 이용에 가장 영향력 있는 선행변수임을 제시하며 $(\beta=0.32)$ 반면, 경제적 가치가 모바 일거래 이용에 미치는 효과는 다른 가치들에 
비해 상대적으로 낮게 나타났다. 이 결과는 현재 스마트폰 기반 모바일거래를 이용하는 사람들이 금전적인 혜택보다는 시간적인 혜택 에 더 높은 가치를 부여하고 있음을 시사한다. 그러므로 기업은 스마트폰 기반 모바일거래를 활성화하기 위해서 무엇보다도 이용자에게 시 간적인 측면의 혜택들을 제공하는 것이 중요 하다. 특히, 본 연구는 모바일거래 이용의 핵 심 가치로서 시간적 가치를 제시하고 이의 효 과를 규명하였다는 점에서 학문적 시사점을 제공할 수 있을 것이다.

\section{2 연구의 한계점 및 향후 연구 방향}

본 연구의 한계점은 다음과 같다. 첫째, 본 연구는 모바일거래 상황에 초점을 맞추어 이 용자체에서 재미와 기쁨을 추구하는 쾌락적 이용 상황의 변수들을 고려하지 않았다. 향후 연구는 실용적 및 쾌락적 이용 상황을 모두 고 려하여, 이용 상황에 따라 이용자 가치가 이용 의도에 미치는 효과가 어떻게 달라지는지 연구 해 볼 수 있을 것이다. 유사하게, Nysveen 등 [46]은 SMS, 게임, $\mathrm{SNS}$, 지불 서비스의 모바 일서비스를 목표지향적/인적상호작용과 쾌락 적/기계적상호작용의 두 가지 상황으로 구분 하고 각각의 상황에서 이용의도에 더욱 영향 력 있는 가치는 무엇인지 밝히고자 시도한 바 있다. 둘째, 본 연구에서 응답자들이 가장 많 이 이용하는 스마트폰 기반 모바일거래 서비 스는 모바일 뱅킹, 모바일 쇼핑, 기차표/버스 표 구입 순으로 나타났다. 이들 서비스는 모 두 이용자의 쾌락적 목적보다는 실용적 목적 에 의해 주도되지만, 본 연구에서는 각각의 서비스가 가지는 고유한 특성들을 반영하지
못하였다는 점에서 한계가 있다. 예를 들어, 모바일 뱅킹과 모바일 쇼핑 상황에서, 이용자 는 시간적, 기능적, 경제적 가치에 서로 다른 평가를 내릴 수 있을 것이다. 그러므로 향후 연구에서는 모바일거래 서비스의 유형에 따라 이용자의 가치 평가에 어떠한 차이가 발생하 는지를 분석해 볼 수 있을 것이다. 마지막으 로, 본 연구에서 이용한 샘플의 대다수가 20 대의 여성으로 구성되어 있다는 점이다. 하지 만, 스마트폰 기반 모바일거래를 통해 추구하 는 가치가 연령대별 또는 성별에 따라 차이가 존재할 수 있다. 즉, 20 대의 경우는 실용적 가 치(지각된 유용성)보다는 쾌락적 가치(지각된 즐거움)을 더욱 추구하는 경향이 강하지만 3 0 40대의 연령대인 경우에는 사회적 가치나 실용적 가치가 더욱 강조될 수 있다. 예를 들 어, $\operatorname{Han}[24]$ 는 20대에서 40대 남녀 소비자를 대상으로 스마트폰 소비행태, 소비가치 등을 분석한 결과 연령대별 소비행태에 차이가 존 재함을 발견하였다. 그리고 20대는 스마트폰을 통해 게임, 음악, 정보검색 등을 가장 많이 이 용하는 반면에 40대는 뉴스와 이메일 확인, 인 터넷 뱅킹 등을 가장 많이 이용한다고 제시하 였다. 그러므로 향후 연구에서는 연령대별로 그리고 성별로 모바일 서비스의 이용에서 서로 다른 가치의 차이를 반영해 볼 수 있을 것이다.

\section{References}

[1] Ajzen, I., "The Theory of Planned Behavior," Organizational Behavior and Human Decision Processes, Vol. 50, No. 2, pp. 
179-211, 1991.

[2] Babin, B. J. and Darden, W. R., "Consumer Self-Regulation in a Retail Environment," Journal of Retailing, Vol. 71, No. 1, pp. 47-70, 1995.

[3] Babin, B. J., Darden, W. R., and Griffin, M., "Work and/or Fun : Measuring Hedonic and Utilitarian Shopping Value," Journal of Consumer Research, Vol. 20, March, pp. 644-656, 1994.

[4] Balasubramanian, S., Peterson, R. A., and Jarvenpaa, S. L., "Exploring the Implications of $\mathrm{M}$-Commerce for Markets and Marketing," Journal of the Academy of Marketing Science, Vol. 30, No. 4, pp. 348-361, 2002.

[5] Bateson, J. E. G. and Hui, M. K., "Perceived Control as a Crucial Perceptual Dimension of the Service Experience : An Experimental Study," in Add Value to Your Service, C. F. Surprenant, (Ed.), Chicago : American Marketing Association, pp. 187-192, 1987.

[6] Bateson, J. E. G., "Self-Service Consumer : An Exploratory Study," Journal of Retailing, Vol. 61, No. 3, pp. 49-76, 1985.

[7] Bergadaà, M. M., "The Role of Time in the Action of the Consumer," Journal of Consumer Research, Vol. 17, No. 3, pp. 289-302, 1990.

[8] Berry, L. L., Seiders, K., and Grewal, D., "Understanding Service Convenience," Journal of Marketing, Vol. 66, No. 3, pp. 1-17, 2002.
[9] Bobbit, L. M. and Dabholkar, P. A., "Integrating Attitudinal Theories to Understand and Predict Use of Tehcnologybased Self-Service," International Journal of Service Industry Management, Vol. 12, No. 5, pp. 423-450, 2001.

[10] Brady, M. K., Knight, G. A., Cronin, J. J., Hult, G. T., and Keillor, B. D., "Removing the Contextual Lens : A Multinational, Multi-setting Comparison of Service Evaluation Models," Journal of Retailing, Vol. 81, No. 3, pp. 215-230, 2005.

[11] Brown, S. A., Dennis, A. R., and Venkatesh, V., "Predicting Collaboration Technology Use : Integrating Technology Adoption and Collaboration Research," Journal of Ma- nagement Information Systems, Vol. 27, No. 2, pp. 9-53, 2010.

[12] Childers, T. L., Carr, C. L., Peck, J., and Carson, S., "Hedonic and Utilitarian Motivations for Online Retail Shopping Behavior," Journal of Retailing and $\mathrm{Co}^{-}$nsumer Services, Vol. 77, No. 4, pp. 511-535, 2001.

[13] Chin, W., "Issues and Opinion on Structural Equation Modeling," MIS Quarterly, Vol. 22, No. 1, pp. 7-16, 1998.

[14] Choi, B. and Lee, J., "The Influence of Customer Readiness in Advance on Service Quality and Customer Value in Self-Service Technology : The Case of Online Shopping," Korean Management Review, Vol. 40, No. 5, pp. 1347-1373, 2011. [15] Choi, S., "Examining Determinants of Social Network Service(SNS) Use Based 
on Smartphones : Focusing on Technical, Hedonic, and Social Characteristics," Journal of Information Technology Applications and Management, Vol. 19, No. 4, pp. 76-95, 2012.

[16] Collier, J. E. and Sherrell, D. L., "Examining the Influence of Control and Convenience in a Self-Service Setting," Journal of the Academy of Marketing Science, Vol. 38, pp. 490-509, 2010.

[17] Dabholkar, P. A., "Consumer Evaluations of New Technology-based Self-Service Options : An Investigation of Alternative Models of Service Quality,” International Journal of Research in Marketing, Vol. 13, No. 1, pp. 29-51, 1996.

[18] Dabholkar, P. A., Bobbit, L. M., and Lee, E. J., "Understanding Consumer Motivation and Behavior Related to SelfScanning in Retailing," International Journal of Service Industry Management, Vol. 14, No. 1, pp. 59-95, 2003.

[19] Davis, F. D., Bagozzi, R. P., and Warshaw, P. R., "User Acceptance of Computer Technology : A Comparison of Two Theoretical Models," Management Science, Vol. 35, No. 8, pp. 982-1003, 1989.

[20] Eagly, A. A. and Chaiken, S., Psychology of Attitudes, Fort Worth : Harcourt Brace College, 1993.

[21] Fiore, A. M., Kim, J., and Lee, H. H., "Effect of Image Interactivity Technology on Consumer Responses Toward the Online Retailer," Journal of Interactive Marketing,
Vol. 19, No. 3, pp. 38-53, 2005.

[22] Fishbein, M. and Ajzen, I., Belief, Attitude, Intention and Behavior : An Introduction to Theory and Research, Addison-Wesley, Reading, MA, 1975.

[23] Fornell, C. and Larcker, D. F., "Evaluating Structural Equations with Unobservable Variables and Measurement Error," Journal of Marketing Research, Vol. 18, No. 1, pp. 39-50, 1981.

[24] Han, S., "A Study on the Consumption Value and the Consumption Satisfaction of Smart Phone Users," Journal of Consumer Studies, Vol. 22, No. 3, pp. 233-260, 2011.

[25] Hirschman, E. C. and Holbrook, M. B., "Hedonic Consumption : Emerging Concepts, Methods and Propositions," Journal of Marketing, Vol. 46, No. 3, pp. 92-101, 1982.

[26] Holbrook, M. B. and Hirschman, E. C., "The Experiential Aspects of Consumption : Consumer Fantasies, Feelings, and Fun," Journal of Consumer Research, Vol. 9, No. 2, pp. 132-140, 1982.

[27] Holbrook, M. B., "The Nature of Customer Value: An Axiology of Services in the Consumption Experience," in Service $\mathrm{Qu}^{-}$ ality : New Directions in Theory and Practice, Roland T. Rust and Richard L. Oliver, (Eds), Newbury Park, CA : Sage, pp. 21-71, 1994.

[28] Hong, S. and Tam, K. Y., "Understanding the Adoption of Multipurpose Information 
Appliances : The Case of Mobile Data Services," Information Systems Research, Vol. 17, No. 2, pp. 162-179, 2006.

[29] Hourahine, B. and Howard, M., "Money on the Move : Opportunities for Financial Service Providers in the 'Third Space," Journal of Financial Services Marketing, Vol. 9, pp. 57-67, 2004.

[30] Howard, J. A. and Sheth, J. N., The Theory of Buyer Behavior, John Wiley and Sons Ltd, 1969.

[31] Jang, K. and Kim, K., "A Study on Factors Affecting the Continued Usage Intention of Ubiquitous Services," The Journal of Information Systems, Vol. 17, No. 3, pp. 175-204, 2008.

[32] Kannan, P. K., Chang, A. M., and Whinston, A. B., "Wireless Commerce : Marketing Issues and Possibilities," Proceedings of the 34th Hawaii International Conference on System Science, IEEE Computer Society Press, Los Alamitos, 2001.

[33] Kim, E. and Mun, H., "The Effect of Perceived Time on Intention to Use Mobile Service-Considering the Moderating Effect of Ubiquitous," The Journal of Information Systems, Vol. 18, No. 3, pp. 155-181, 2009.

[34] Kim, H., Gupta, S., and Koh, J., "Investigating the Intention to Purchas Digital Items in Social Networking Communities : A Customer Value Perspective," Information and Management, Vol. 48, pp. 228-234, 2011.

[35] Kleijnen, M., de Ruyter, K., and Wetzels,
M., "An Assessment of Value Creation in Mobile Service Delivery and the Moderating Role of Time Consciousness," Journal of Retailing, Vol. 83, No. 1, pp. 33-46, 2007.

[36] Korgaonkar, P. K. and Wolin, L. D., “A Multivariate Analysis of Web Usage," Journal of Advertising Research, Vol. 39, No. 2, pp. 53-68, 1999.

[37] Langeard, E., Bateson, J., Lovelock, C. H., and Eiglier, P., Service Marketing : New Insights from Consumers and Managers, Marketing Science Institute's Report No pp. 81-104, Cambridge : Marketing Science Institute, 1981.

[38] Lee, I., Choi, B., Kim, J, Hong, S., "Culture-Technology Fit : Effects of Cultural Characteristics on the Post-Adoption Beliefs of Mobile Internet Users," International Journal of Electronic Commerce, Vol. 11, No. 4, pp. 11-51, 2007.

[39] Lee, J. and Kim, Y., "A Study on the Impact of the App-Book Purchasing Behavior of Smart phone Users in Korea," The Journal of Society for e-Business Studies, Vol. 18, No. 3, pp. 45-67, 2013.

[40] Lee, T., La, S., and Yeon, S., "MOBISQUAL : Dimensionalizing and Measuring Mobile Internet Service Qaulity," Journal of Korean Marketing Association, Vol. 24, No. 1, pp. 145-179, 2009.

[41] Lee, U., Kim, K., and Lee, J., "The Effect of Community Artifacts and Media Richness Elements on the Experiences of the 
Social Network Game Users : 'Anypang' Case," The Journal of Society for $\mathrm{e}^{-} \mathrm{Bu}^{-}$ siness Studies, Vol. 18, No. 3, pp. 191-211, 2013.

[42] Lee, Y., Park, J., Chung, N., and Blakeney, A., "A Unified Perspective on the Factors Influencing Usage Intention Toward $\mathrm{Mo}^{-}$ bile Financial Services," Journal of Business Research, Vol. 65, No. 11, pp. 15901599, 2012.

[43] Lu, H. and Hsiao, K., "The Influence of Extro/Introversion on the Intention to Pay for Social Networking Sites," Information and Management, Vol. 47, pp. 150-157, 2010.

[44] Mathwick, C., Malhotra, N., and Rigdon, E., "Experiential Value : Conceptualization, Measurement and Application in the $\mathrm{Ca}^{-}$ talog and Internet Shopping Environment," Journal of Retailing, Vol. 77, No. 1, pp. 39-56, 2001.

[45] Meuter, M. L., Ostrom, A. L., and Roundtree, R. I., and Bitner, M. J., "Self-Service Technologies : Understanding Customer Satisfaction with Technology-Based Service Encounters," Journal of Marketing, Vol. 64, July, pp. 50-64, 2000.

[46] Nysveen, H., Pedersen, P. E. and Th $\varnothing$ rbjornsen, H., "Intentions to Use Mobile Services : Antecedents and Cross-Service Comparisons," Journal of the Academy of Marketing Science, Vol. 33, No. 3, pp. 330-346, 2005.

[47] Petrick, J. F., "Development of a Multi-
Dimensional Scale for Measuring the Perceived Value of a service," Journal of Leisure Research, Vol. 34, No. 2, pp. 119-134, 2002.

[48] Pujari, D., "Self-Service with a Smile? Self-Service Technology (SST) Encounters among Canadian Business-to-Business," International Journal of Service Industry Management, Vol. 15, No. 2, pp. 200-219, 2004.

[49] Ringle, C. M., Sarstedt, M., and Straub, D. W., "A Critical Look at the Use of PLS-SEM in MIS Quarterly," MIS Quarterly, Vol. 36, No. 1, pp. iii-xiv, 2012.

[50] Ringle, C. M., Wende, S., and Will, S., SmartPLS 2.0 (M3) Beta, Hamburg, http : //www.smartpls.de, 2005.

[51] Roulac, S. E., "Retail Real Estate in the 21st Century : Information + Time Consciousness + Unintelligent Stores $=$ Intelli gent Shopping? Not!" The Journal of Retail Estate Research, Vol. 9, No. 1, pp. 125-150, 2001.

[52] Shankar, V., O’Driscoll, T., and Reibstein, D., "Rational Exuberance: The Wireless Industry's Killer B," Strategy and Business, Vol. 31, Summer, pp. 68-77, 2003.

[53] Sheth, J. N., Newman, B. I., and Gross, B. L., "Why We Buy What We Buy : A Theory of Consumption Values," Journal of Business Research, Vol. 22, pp. 159-170, 1991.

[54] Sweeney, J. C. and Soutar, G. N., "Consumer Perceived Value : The Development of a 
Multiple Item Scale, Journal of Retailing, Vol. 77, No. 2, pp. 203-220, 2001.

[55] Tenenhaus, M., Vinzi, E. V., Chatelin, Y. M., and Lauro, C., "PLS Path Modeling," Computational Statistics and Data Analysis, Vol. 48, No. 1, pp. 159-205, 2005.

[56] Tojib, D. and Tsarenko, Y., "Post-Adoption Modeling of Advanced Mobile Service Use,” Journal of Business Research, Vol. 65, pp. 922-928, 2012.

[57] Turel, O., Serenko, A., and Bontis, N., "User Acceptance of Hedonic Digital Artifacts : A Theory of Consumption Values Perspective," Information and Management, Vol. 47, pp. 53-59, 2010.

[58] Turel, O., Serenko, A., and Bontis, N., "User Acceptance of Wireless Short Messaging Services : Deconstructing Perceived Value," Information and Management, Vol. 44, pp.
63-73, 2007.

[59] Yoo, H., Kim, M., and Kwon, O., "Factors Influencing Acceptance of Hedonic Ubiquitous Services," The Journal of Society for e-Business Studies, Vol. 17, No. 1, pp. 1-21, 2012.

[60] van der Heijden, H., "User Acceptance of Hedonic Information Systems," MIS Quarterly, Vol. 28, No. 4, pp. 695-704, 2004.

[61] Venkatesh, V., Thong, J. Y. L., and Xu, $\mathrm{X}$., "Consumer Acceptance and Use of Information Technology : Examining the Unified Theory of Acceptance and Use of Technology,” MIS Quarterly, Vol. 36, No. 1, pp. 157-178, 2012.

[62] Zeithaml, V. A., "Consumer Perceptions of Price, Quality, and Value : A Means-End Model and Synthesis of Evidence," Journal of Marketing, Vol. 52, July, pp. 2-22, 1988. 


\section{저 자 소 개}

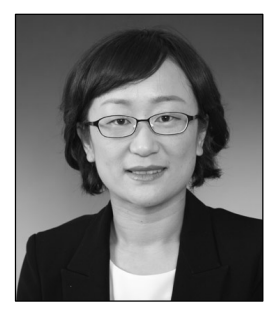

최수정

(E-mail : mischoisj@jnu.ac.kr)

1999년

목포대학교 경영학과 (학사)

2001년

전남대학교 경영학과 (석사)

2005년

전남대학교 경영학과 (박사)

2005년

한국콜센터산업정보연구소 책임연구원

2008년

전남대학교 경영학과 $\mathrm{BK} 21$ 연구교수

2010년

미국 Purdue University 방문연구원

2013년 현재

전남대학교 Free $21+\mathrm{e}^{-}$서비스 사업단 연구교수

관심분야

Electronic Collaboration(B2B), Call center and CRM, SNS 